\title{
THE PHILOSOPHY AND METHODOLOGY OF ISLAM-SCIENCE INTEGRATION: Unravelling the Transformation of Indonesian Islamic Higher Institutions
}

\author{
Khozin and Umiarso ${ }^{1}$ \\ Universitas Muhammadiyah Malang \\ Email: khozin@umm.ac.id, umiarso@umm.ac.id
}

\begin{abstract}
The transformation of Islamic higher education into State Islamic University (Universities Islam Negeri/UIN) necessitates the changing of scientific thoughts. Before this transformation, Islamic higher education 's core business is commonly concerned with the teaching of Islamic sciences, while UIN includes the instruction of general sciences, e.g., natural and social Sciences. In fact, the two (Islamic and natural-social science) should be integrated into the Islamic high education to establish a new integrated scientific paradigm. This study focuses mainly on the philosophy and the integration of science and Islamic methodologies in Indonesia. Based on the phenomenological qualitative approach, the current study critically examines Islam and science integration. Grounded on the study of three UINs, the article shows a novel paradigm that enables the integration of science and religion in those universities. Each university offers a specific character of the integration. UIN of Malang, for example, initiates the integration which is reflected in "tree of science". UIN of Yogyakarta offers the metaphor of "spider web" for its interconnected and integrated Islam and science project while UIN of Surabaya proposes multidisciplinary-integration with the metaphor of integrated twin towers.
\end{abstract}

Keywords: Philosophy base, scientific integration, and metaphor DOI: https://doi.org/10.20414/ujis.v23i1.359

\footnotetext{
${ }^{1}$ Corresponding author
} 


\section{Introduction}

THE ISLAMIC religious higher educational institution (Perguruan Tinggi Keagamaan Islam [PTKI]) in Indonesia continues to experience rapid changes, especially in the last two decades. This change has been investigated by scholars from various disciplines with a different focus of study. Arifa's research focuses on the field of institutional management, ${ }^{2}$ while Sari's research is concerned with institutional roles and functions. ${ }^{3}$ Suyatman explores the ideal of institutional change, ${ }^{4}$ while Muflihin's research examines changing curriculum. ${ }^{5}$ There is also research that uses the scientific paradigm of institutional change by Lukman. ${ }^{6}$ Therefore, changes in the status of Islamic institution from Sekolah Tinggi Agama Islam Negeri/STAIN (State College of Islamic Studies) and Institut Agama Islam Negeri/IAIN (State Institute of Islamic Studies) into Universitas Islam Negeri/UIN (State Islamic University) should not be understood merely as an sich institutional transformation. Furthermore, institutional changes necessitate transformation in "scientific thinking" and subjects.

For example, STAIN and IAIN teach subjects relating mainly to Islamic sciences (Islamic studies), such as Islamic education

${ }^{2}$ Laily Nur Arifa, "Perubahan STAIN/IAIN Menjadi UIN Sebagai Bentuk Pengembangan Pendidikan Tinggi Islam: Contoh Kasus Perubahan STAIN Menjadi UIN Malang Perspektif Manajemen Perubahan Kurt Lewin," Vicratina: Jurnal Pendidikan Islam 2, no. 1 (2017): 27-42, http://riset.unisma.ac.id/index. php/fai/article/view/265.

${ }^{3}$ Ramadhanita Mustikan Sari, "Perguruan Tinggi Islam dan Transformasi Lembaga: Studi Terhadap Proses Perubahan Fungsi dan Peran IAIN Syarif Hidayatullah Jakarta Menjadi Universitas Islam," El-Hekam 1, no. 1 (2016): 1-18, http://ecampus.iainbatusangkar.ac.id/ojs/index.php/elhekam/article/view/334.

${ }^{4}$ Ujang Suyatman, "Manajemen Strategik dalam Transformasi IAIN Menjadi UIN," Jurnal Administrasi Pendidikan 14, no. 1 (2012): 33-59, https://ejournal. upi.edu/index.php/JAPSPs/article/view/6705.

5 Ahmad Muflihin, "Paradigma Keilmuan Integrasi-Interkoneksi: Studi Terhadap Desain dan Implementasi Kurikulum Program Magister Prodi Pendidikan Islam Fakultas Ilmu Tarbiyah dan Keguruan UIN Sunan Kalijaga Yogyakarta" (Thesis Post-Graduate, UIN Sunan Kalijaga, 2016).

${ }^{6}$ Fadhli Lukman, “Integrasi-Interkoneksi Dalam Studi Hadis Disertasi UIN Sunan Kalijaga Yogyakarta," Religia: Jurnal Ilmu-Ilmu Keislaman 12, no. 2 (February 20, 2017): 1-11, accessed June 3, 2019, http://e-journal. iainpekalongan.ac.id/index.php/Religia/article/view/746. 
(tarbiya), Islamic law (sharia), history, civilization and literature ('adab), propagation $\left(d a^{\prime} w a\right)$ and theology (ușūl al-dīn). After the transformation into UIN, subjects of the study expand and cover natural sciences, social sciences and humanities. In the view of UIN, Islamic sciences must be integrated with general sciences. The view rejects the separation of science and religion as this partly still occurs, and is expressed, in the division of "general universities" under the administration of the Ministry of Education and "Islamic universities" under the auspices of the Ministry of Religious Affairs. ${ }^{7}$ Clearly, the direction of the change is aimed at building an integral and comprehensive education system in various disciplines of science. ${ }^{8}$

The integration of science and Islam as desired by PTKI then raises a new problem that is concluded in two big questions: what is the philosophical and theological basis for such religion-science integration? What is the methodology of the integration of religion and science, and how to apply this method? The problem of integration has so far attracted debate between those who agreed with those who refused. The controversy is mainly triggered by a number of issues; First, the tragic history of the relationship between science and religion (as this was reflected in the medieval church traditions), ${ }^{9}$ and its implications for the Islamic world -or the rise of Islamic science. ${ }^{10}$ Although in principle Islam does not recognize the dichotomy of science and religion, the knowledge integrated with Islam is the modern sciences which inherit Western secular culture and civilization, not the product of sciences yielded from Islamic civilization. Epistemologically, the integration of science and Islam in this context is certainly a complex problem.

Second, the integration of science and Islam is a philosophical

${ }^{7}$ M. Amin Abdullah, Islamic Studies di Perguruan Tinggi Pendekatan IntegratifInterkonektif (Yogyakarta: Pustaka Pelajar, 2006), 54.

${ }^{8}$ Muhbib Abdul Wahab, "Pendidikan Islam Holistik Berbasis Nilai dalam Perspektif Sirah Nabi," in Pendidikan Holistik: Pendekatan Lintas Pespektif, ed. Jejen Musfah (Jakarta: Kencana, 2012), 327.

${ }^{9}$ See John William Draper, History of The Conflict Between Religion and Science (New York: D. Appleton and Company, 1986).

${ }^{10}$ Muzaffar Iqbal, Science and Islam (London: Greenwood Press, 2007), 3. 
idea that is not easily realizable even in high education. Take, for example, the rejection on the idea of "Islamization of contemporary knowledge" by Al-Attas ${ }^{11}$ and al-Faruqi. ${ }^{12}$ This issue receives a broad response from Muslim scholars, such as Idris. ${ }^{13}$ Sayyed Hosen Nasr is a scholar who also discussed the fundamental differences between science from a Western perspective and from an Islamic perspective. ${ }^{14}$ The argument goes on to say that considering knowledge originating from the West as merely a continuation of the Islamic sciences was a big mistake because both subscribe to different epistemology regarding science and revelation. Sardar promotes the idea of the need for a new paradigm as a parameter of Islamic sciences more firmly. ${ }^{15}$ Some Indonesian Muslim scholars also involved themselves in this conversation, such as Bakar, ${ }^{16}$ Soewardi, ${ }^{17}$ Kartanegara, ${ }^{18}$ and Heriyanto ${ }^{19}$.

${ }^{11}$ Syed Muhammad Naquib Al-Attas, Islam and Secularism (Kuala Lumpur: ISTAC, 1993).

${ }^{12}$ Ismail Raji' al-Faruqi, Islamization of Knowledge: General Principles and Work Plan (Herndon: IIIT, 1989).

${ }^{13}$ Jaafar Sheikh Idris, "The Islamization of the Sciences: Philosophy and Methodology," The American Journal of Islamic Social Sciences 4, no. 2 (1987): 201208.

${ }^{14}$ Seyyed Hossein Nasr, Menjelajah Dunia Modern, trans. Histi Tarekat (Bandung: Mizan, 1994).

${ }^{15}$ Ziauddin Sardar, Rekayasa Masa Depan Peradaban Muslim, trans. Rahmani Astuti (Bandung: Mizan, 1993); Ziauddin Sardar, ed., The Touch of Midas: Science, Values and Environment in Islam and The West (Manchester: Manchester University Press, 1984). see also in Kurnia Sari Wiwaha, "Epistemologi Paradigma Islam: Studi Pemikiran Ziauddin Sardar," Religious: Jurnal Studi Agama-Agama dan Lintas Budaya 3, no. 1 (2018): 70-79, http://journal.uinsgd.ac.id/index.php/Religious/ article/view/3673.

16 Osman Bakar, Hierarki Ilmu, Membangun Rangka Pikir Islamisasi Ilmu: Menurut al-Farabi, al-Ghazali, Qutb al-Din al-Syirabi, trans. Purwanto (Bandung: Mizan, 1998).

${ }^{17}$ Herman Soewardi, Roda Berputar Dunia Bergulir: Kognisi Baru Tentang Timbul Tenggelamnya Sivilisasi (Bandung: Bakti Mandiri, 1999).

18 Mulyadhi Kartanegara, Integrasi Ilmu: Sebuah Rekonstruksi Holistik (Bandung: Arasy, 2005); Mulyadhi Kartanegara, Nalar Religius: Memahami Hakikat Tuhan, Alam, dan Manusia (Jakarta: Erlangga, 2007).

${ }^{19}$ Husein Heriyanto, Paradigma Holistik: Dialog Filsafat, Sains, dan Kehidupan Menurut Shadra dan Whitehead (Jakarta: Teraju, 2003). 
Third, there is an objection or even the refusal from scientists to the idea of Islamization of knowledge. Muslim scholars such as Rahman, Salam and Hoodbhoy reject the Islamization of knowledge. According to Rahman, 'ilm (knowledge) is itself good, so it does not need to be Islamic. ${ }^{20}$ However, abuse of science may happen for the sake of a particular objective. The implementation of knowledge depends on moral priority because moral is the most important of all. Rahman refers to some Qur'anic verses to support his arguments, such as Sura al-Ahzāb [72] and Sura 'Abasa [23]. Other scholars, such as Hoodbhoy even write a particular book to reject the idea of the Islamization of knowledge. According to him,,$^{21}$ there is only one universal science. There is no such thing as Islamic science or Hindu science, Jewish science, Confucian science, and Christian Science. His book receives support from other scholars as well. ${ }^{22}$ Indonesia scholars Kuntowijoyo and Usep Fathuddin, are amongst those who sharply criticize Islamization of knowledge and promote another term they think of more suitable, namely "Islamic scholarship". Meanwhile Fathudin considers Islamization of knowledge as contradictio in terminis or terminologically wrong concept because this implies that there is Islamic and non-Islamic knowledge.

The controversy over the idea of Islamization of knowledge, however, does not discourage Muslim academia from PTKI to think that the issue is simply settled. Islam and knowledge integration remains debatable, and efforts to theoretically integrate them to continue. This enthusiasm is mainly driven by problems of current Islamic knowledge and science that do not provide answers to a social problem, thus provoking the idea of integration. New arising social problems require integrative knowledge to find a holistic-comprehensive solution. For this purpose, Muslim scholars then construct a theological and philosophical foundation that brings together Islam and science. So far, the theological and philosophical foundation of the

${ }^{20}$ Fazlur Rahman, "Islamization of Knowledge: A Response," Islamic Studies 50, no. 3/4 (2011): 449-457, www.jstor.org/stable/41932607..

${ }^{21}$ Pervez Hoodbhoy, Ikhtiar Menegakkan Rasionalitas antara Sains dan Ortodoksi Islam, trans. Sari Meutia (Bandung: Mizan, 1996).

${ }^{22}$ Frank J. Tipler, The Physics of Christianity (Toronto: Doubleday, 2007), 116. 
integration of science and Islam has attracted Muslim scholars academics to address it. Meanwhile, in terms of methodology, they have different perspectives on how the integration is realized and implemented into the educational system. The proposed methodology still leaves problems among scholars involved in the discourse of the integration of science and Islam. ${ }^{23}$ One critic, for example, said that there are internal debates amongst the PTKI scholars as to whether or not the changing institution from STAIN and IAIN to UIN is necessary and whether the idea of integration fits to the basic core business of PTKI. ${ }^{24}$

Indeed, academically, there are scholars trying to elaborate the concept of integration of science and religion, such as Barbour, ${ }^{25}$ Guessoum, ${ }^{26}$ or Bucaille. ${ }^{27}$ There is also a research which unravels in-depth and details the dynamics of the integration of science and Islam with the scientific, theological approach. ${ }^{28}$ There are also a number of studies that have explored the implementation of the integration of science and Islam in Islamic education institutions. ${ }^{29}$

${ }^{23}$ Fathul Mufid, "Islamic Sciences Integration," Qudus International Journal of Islamic Science 2, no. 2 (2014): 144-160, http://journal.stainkudus.ac.id/index. php/QIJIS/article/view/1565.

${ }^{24}$ Ronald A. Lukens-Bull, Islamic Higher Education In Indonesia: Continuity and Conflict (New York: Palgrave McMillan, 2013).

${ }^{25}$ Ian G. Barbour, When Science Meets Religion (New York: Harper SanFracisco, 2002); Ian G. Barbour, “On Typologies for Relating Science and Religion," Journal of Religion $\mathcal{E}$ Science 37, no. 2 (2002): 345-360, https://onlinelibrary.wiley.com/doi/abs/10.1111/0591-2385.00432.

${ }^{26}$ Nidhal Guessoum, Islam Dan Sains Modern: Bagaimana Mempertemukan Islam Dengan Sains Modern, trans. Maufur (Bandung: Mizan, 2014).

${ }^{27}$ Maurice Bucaille, The Bible, The Qur'an, and Science: The Holy Scriptures Examined in The Light of Modern Knowledge (New York: American Trust Publications, 1978).

${ }^{28}$ Badarussyamsi, "Spiritualitas Sains Dalam Islam: Mengungkap Teologi Sainstifik Islam," MIQOT: Jurnal Ilmu-ilmu Keislaman 39, no. 2 (2015): 255-275, http://jurnalmiqotojs.uinsu.ac.id/index.php/jurnalmiqot/article/view/17.

${ }^{29}$ Muhammad Munadi, "Integration of Islam and Science: Study of Two Science Pesantrens (Trensain) in Jombang and Sragen," Jurnal Pendidikan Islam 5, no. 2 (December 15, 2016): 287-303, http://ejournal.uin-suka.ac.id/tarbiyah/ index.php/JPI/article/view/1236; Rabiatul Adawiyah, "Integrasi Sains dan Agama dalam Pembelajaran Kurikulum PAI (Perspektif Islam dan Barat serta Implementasinya)," Al-Banjari: Jurnal Ilmiah Ilmu-Ilmu Keislaman 15, no. 1 (May 15, 2016): 99-124, http://jurnal.uin-antasari.ac.id/index.php/al-banjari/article/ 
These studies describe the construction of the integration of science and Islam in learning the curriculum of Islamic education. Another study by Anshori and Abidin examine the integration of science and Islam and its implementation in four state and private institutions..$^{30}$ Meanwhile, Aziz's research analyzes the process of changing status, which is inseparable from the process of integration of science and Islam. ${ }^{31}$

However, those studies have not questioned the fundamental problem related to the pattern or basis of the philosophy and methodology of the integration of science and Islam which serves the ground for changes in the institutional status of Islamic universities. Therefore, this present study aims to discuss these two dimensions (philosophical and methodological bases) and examines the basic framework of scientific integration that accompanies changes in Islamic universities. Based on this rationale, this research employed the qualitative phenomenological study to figure out the answers to the main purpose of the study. The research sites chosen in this study are UIN Maulana Malik Ibrahim Malang, UIN Sunan Ampel Surabaya, and UIN Sunan Kalijaga Yogyakarta since they have adopted the concept of Islam-science integration. This research then summarizes the experimentation of the integration of science and Islam in these three state Islamic universities (UIN). The study uses various documents relating to the integration of science and Islam, such as works of scholars from these three universities that reflect the paradigm of integration. However, the study does not use the technique of interview for the data collection.

view/817; Hayat Hayat, "Integrasi Agama dan Sains Melalui Mata Kuliah PAI di Perguruan Tinggi," INSANIA: Jurnal Pemikiran Alternatif Kependidikan 19, no. 2 (2014): 254-272, http://ejournal.iainpurwokerto.ac.id/index.php/insania/article/ view/715.

${ }^{30}$ Anshori and Zaenal Abidin, "Format Baru Hubungan Sains Modern dan Islam (Studi Integrasi Keilmuan Atas UIN Yogyakarta dan Tiga Universitas Islam Swasta Sebagai Upaya Membangun Sains Islam Seutuhnya Tahun 2007-2013)," Profetika Jurnal Studi Islam 15, no. 1 (June 6, 2016): 90-108, http://journals.ums.ac.id/index.php/profetika/article/view/1969.

${ }^{31}$ Abdul Aziz, "Paradigma Integrasi Sains dan Agama: Upaya Transformasi IAIN Lampung Kearah UIN," Al-Adyan: Jurnal Studi Lintas Agama 8, no. 2 (2013): 67-90, http://ejournal.radenintan.ac.id/index.php/alAdyan/article/view/587. 


\section{Integration of Science and Islam: Between Theological and Philosophical Basis}

Although there is an argument among academicians about the integration of science and Islam, this phenomenon continues to attract academic attention. There are at least two main issues: theological and philosophical. From the theological point of view, Islam does not contradict science, and it supports the integration of religion and religion. This view was expressed, for example, by Faruqi and his concept on IIIT (International Institute of Islamic Thought), Herman Soewardi ${ }^{32}$ and Wan Daud. ${ }^{33}$ They base their arguments on the Qur'an, namely Sura al-'Alaq [4 and 5], which states that "who taught by the pen, taught man what he did not know". Ahmad Tafsir, professor at UIN Sunan Gunung Djati Bandung, suggests that the Sura al-Baqara [32] is confirmation that knowledge comes from Allah. ${ }^{34}$ This verse expressly states that "Exalted are You; we have no knowledge except what You have taught us. Indeed, it is You who is the Knowing, the Wise". The verses of 190191 in the same sura encourage people to continually study the phenomena of the universe so that they may reach the level of $u l u l$ albab (knowledgeable).

The philosophical basis of the integration between science and Islam itself is put forward by al-Faruqi, Kartanegara, Tafsir and Rahman. Faruqi states that epistemologically in Islam, truth derives from the absolute oneness of Allah. The ambiguous truth, such as the truth of science and religion, is illogical and tends to be paradoxical. ${ }^{35}$ Therefore, theoretically, there is no discrepancy between the truth of revelation and that of natural law. The logical compatibility between empirical truths, the reason for truths, and truths conveyed by revelation is the most critical principles in the theory of knowledge. This conformity according to al-Faruqi is

32 Soewardi, Roda Berputar Dunia Bergulir, 56.

${ }^{33}$ Wan Mohd Nor Wan Daud, Filsafat dan Praktik Pendidikan Islam Syed M. Naquib al-Attas, trans. Hamid Fahmy et.al. (Bandung: Mizan Media Utama, 2003), 47.

${ }^{34}$ Ahmad Tafsir, "Basis Filsafat untuk Integrasi Pengetahuan Quraniyah dan Pengetahuan Kauniyah," in The International Seminar UIN Sunan Gunung Djati Bandung, 2011.

35 al-Faruqi, Islamization of Knowledge, 24. 
based on the three principles of unity of truth that underlie all Islamic knowledge; that there is no contradiction between empirical truth and what is revealed by revelation; that there is no conflict between reason and revelation; and all results of the study of natural laws or patterns found in the universe or each part of it are temporary.

Kartanegara's view on the basis of the integration of science and Islam is also in line with al-Faruqi's view. Kartanegara states that Muslim scientists will believe that the source of knowledge is Allah, the God, whom they call The Truth (Al-Haqq) or, as others recall, The Ultimate Reality. ${ }^{36}$ Because the purpose of science is to know something as it really is, which means to know the true truth, God as the true truth is certainly the source of all other truths, including the truth of the realities of science. The Qur'an explicitly says "The truth is from your Lord, so do not be among the doubters" (Sura al-Baqarah [148] and Sura Āli 'Imrān [60]). Thus, Muslim scientists agree that the source of knowledge (or rather the original source or the last source of knowledge) is Allah Himself, The Truth. If interpreted by this statement, it can be said that in fact, there is a philosophical unity, especially in the ontological and axiological dimensions. Therefore, this unity encourages the search for the ideal construction of science that blends with religion or religious-based science. It is natural for al-Faruqi to affirm that "....both the religious sciences and the general sciences actually study "the verses of Allah", in which the former studies the qawliya (norms/laws), while the latter studies the kawniya (universe/nature) verses. ${ }^{37}$ Besides, both are signs (aya) of Allah, and refer to the same True Reality, Allah, as the source of all truth. $\mathrm{He}$ is the reality that becomes the object of research for every

${ }^{36}$ Kartanegara, Integrasi Ilmu, 34.

37 Muhammad Taufik and Muhammad Nasir, "Mengkritisi Konsep Islamisasi Ilmu Ismail Raji al-Faruqi: Tela'ah Pemikiran Ziauddin Sardar," Jurnal Ushuluddin 25, no. 2 (2017): 109-123, http://ejournal.uin-suska.ac.id/index.php/ ushuludin/article/view/3830; Zuhdiyah, "Islamisasi Ilmu Ismail Raji al-Faruqi," Tadrib: Jurnal Pendidikan Agama Islam 2, no. 2 (2016): 293-313, http://jurnal. radenfatah.ac.id/index.php/Tadrib/article/view/1173; Sholeh, "Islamisasi Ilmu Pengetahuan: Konsep Pemikiran Ismail Raji al-Faruqi dan Syed Muhammad Naquib al-Attas," al-Hikmah: Jurnal Agama dan Ilmu Pengetahuan 14, no. 2 (2017): 209-221, https://journal.uir.ac.id/index.php/alhikmah/article/view/1029. 
science. Here, there are two kinds of knowledge finding for the basis of the integration, i.e. in the verses of Allah, in the form of holy books on the one hand and the universe on the other hand.

The same argument is also found in Tafsir's thought, which maintains that Allah is the source of knowledge (al-Baqara [32]). ${ }^{38}$ The source of knowledge provides two loci to be studied (iqra') and examined, e.g., the Qur'an and al-kawn. Reading the Qur'an produces knowledge (theories and concepts), such as natural sciences, social sciences and humanities. Likewise, reading the verses of al-kawn (universe/nature) will produce knowledge relating to natural science. The two categories of knowledge are based on Allah's knowledge, and there is no contradiction in Allah's knowledge. This view shows that the highest source of knowledge is Allah. The Qur'an and al-kawn are the loci that provide such knowledge that can be studied through various approaches, such as bayāni $\bar{\imath}$ (text), burhānī (demonstration), and also irfān̄ (intuition).

Based on this view, it can be said that theologically and philosophically the integration of science and Islam has an undeniable foundation. If there is a conflict between science and religion, then the tension is the only misinterpretation of kawniyya or qur'āniyya. ${ }^{39}$ However, critical problems deal with methodology as to how to integrate Islam and science. Therefore, al-Faruqi proposed 12 steps of the integration: 1) Mastery of modern scientific disciplines; 2) Survey of scientific disciplines; 3) Mastery of Islamic repertoire; 4) Mastery of Islamic Scientific repertoire at the analyst stage; 5) Determination of the typical relevance of Islam to the scientific disciplines; 6) Critical assessment to the modern scientific disciplines; 7) Critical assessment of the Islamic repertoire: the level of development today; 8) Survey of problems faced by Muslims; 9) Survey of problems faced by humankind; 10) Creative and synthesis analysis; 11) Redefining the discipline of modern science into the framework of Islam; and 12) Dissemination of knowledge that has been Islamized.

38 Tafsir, "Basis Filsafat."

${ }^{39}$ Maksudin, Paradigma Agama dan Sains Nondikotomik (Yogyakarta: Pustaka Pelajar, 2016), 56. 
The "agreement" at the operational level in the scope of PTKI has been spread out so that the parts of the institution rely on the integration of science and Islam such as the philosophical basis or aspects of the curriculum. Not surprisingly, Islamic universities have a methodological framework which is different from the foundation of integration. In this scope, comparative critical analysis is needed to look at the philosophical views and methods of integration in several Islamic universities in Indonesia, such as UIN Maliki of Malang, UIN Sunan Amepl of Surabaya, and UIN Sunan Kalijaga of Yogyakarta. This can be found in details regarding the experiment of those Islamic universities in applying the concept of the integration of science and Islam. This effort may be said to be a milestone of Islamic education history in Indonesia. The emergence of PTKI thus will generate the growth of the Islamscience collaboration, which will give a great academic contribution. ${ }^{40}$

\section{The experiment of Integration of Science and Islam}

At present, there are several Islamic universities in Indonesia that have transformed their institutional status from STAIN/IAIN to UIN. Some of these Islamic universities have carried out experiments on the integration of science and Islam. Three of UIN, namely UIN Maliki of Malang, UIN Sunan Kalijaga of Yogyakarta and UIN Sunan Ampel of Surabaya, have been selected in this study as the sample. Each institution has the different philosophical and methodological ground of the integration. This shows the importance of philosophical-methodological bases of the integration and the different interpretation of this aspect from the respective university. It means that the construct of a philosophical view and method cannot be separated from the formulation of the underlying philosophy. This study will, therefore, describe such an experiment at these three universities.

The first case is UIN Maliki Malang. The integration-scientific paradigm with the "Tree of Science" metaphor is carried out by

40 Ronald A. Lukens-Bull, "The Political Use of Islamic Variation in Indonesia Islamic Higher Education," Jurnal Pendidikan Islam 2, no. 2 (2016): 193207, https://journal.uinsgd.ac.id/index.php/jpi/article/view/786. 
UIN Maliki Malang. The dichotomy of sciences and Islam in the view of UIN Maliki Malang is contrary to the nature of universal Islamic teachings. Islamic teachings have never dichotomized between science and religion. Both science and religion are originated from the Qur'an and Hadith. Therefore, the two should not need to be sliced and contested. If there has been any attempt to dichotomize science and religion, then this needs to be returned to the fundamental integrated Islamic paradigm that does not separate religion from science.

Suprayogo, who is the pioneer of experimental projects in the integration of science and Islam at UIN Maliki Malang, has argued that synergizing science and Islam is very crucial, even necessary because ignoring religious values in the development of science and technology will produce negative impacts, not only on the order of social-humanitarian but also on the order of the cosmos or the universe. ${ }^{41}$ The negative impact of the tendency to ignore moral values (religion) can be seen empirically in distorted behaviours carried out by humans on this earth by using the power of science and technology to excessively manipulate the nature. However, on the contrary, the tendency to force normative doctrinal religious teachings into science will also hinder the development of science itself. Therefore, science should not be considered as something final, but it is a process that continues to develop along with the times.

Interestingly, the experiment on the integration of science and Islam at UIN Maliki Malang is built on four philosophical bases. First, the parallelization of religion with philosophy. Religion and philosophy, both of which are normative, and also present a world view, legitimately provide the basis of the development of science. The main argument from the view of the parallelization of religion and philosophy is that philosophy is the basis of science, and science may come religious doctrines. Thus, religion, which is also an unscientific norm, is legitimate as the basis for the development of science.

${ }^{41}$ Imam Suprayogo, "Pendidikan Integralistik: Memadu Sains dan Agama," in Memadu Sains dan Agama Menuju Universitas Islam Masa Depan, ed. M. Zaenuddin et.al. (Malang: UIN Malang Press, 2004), vi. 
Second, the universalism of Islam. Islam is a religion (din $)$ whose teachings are intended for humanity. The universalism of Islam is understood in the sense that Islamic teachings cover all aspects of life which include the principle of teaching that regulates the relationship between humans and God, humans with each other, and humans with their environment. Or it is understood from the dimensions of time and place. Islam is revealed to people in the world regardless of their geographical and ethnic boundaries.

Third, unique characteristics of Islamic teachings that emphasize the balance between spiritual and material life, as well as ritual and social dimensions. UIN Maliki Malang views Islam as a far-flung and infinite religion as vast as the universe, but it still has the harmony of scientific concepts with Islamic teachings. There is no conflict between science and Islam. There is even a meeting point between the two, especially in the function of both. Religion is a way of salvation, while science is a way to prosperity.

Forth, the theory of vortex. Revelation (al-Qur'an and alSunnah) is absolute truth and undeniable, while philosophy and science are products of human thinking, which views the truth as relative. Justification of the higher truth is needed, i.e. the truth of absolute and irrefutable revelations. Therefore, the Qur'an and Hadith are used as a vortex for all sciences, as well as the philosophical basis of science (ontology, epistemology and axiology). These four basic views constitute the philosophical basis for the integration of science and Islam in UIN Maliki Malang.42

These philosophical views have implications on the policies of UIN Maliki Malang, especially on institutional and curriculum policies. Institutionally, they are combined between higher education institutions and high boarding schools ( $m a^{\prime}$ had al-alì) in the campus environment. However, interestingly, higher education has its own curriculum, and so do the high boarding

${ }^{42}$ Khozin, Pengembangan Ilmu di Perguruan Tinggi Keagamaan: Konstruksi Kerangka Filosofis dan Langkah-langkahnya (Jakarta: Kencana, 2016); M. Zainuddin, "Integration of Science and Islam: A Concept and Experience of Maulana Malik Ibrahim State University Malang-Indonesia" (Paper presented at the Workshop Reformulasi Integrasi Sains dan Islam di Perguruan Tinggi, PSIS UIN Malang, September 16, 2014). 
schools. Both of these institutions have different duties and responsibilities. Higher education is given responsibility for scientific development and professionalism, while Islamic high boarding schools are given the task of strengthening spirituality and good moral formation.

From these views as well, UIN Maliki Malang tries to develop an integrated curriculum that is reflected in the form of "Tree of Science". In the root, there are tools of sciences, such as Arabic and English, Basic Natural Sciences and Basic Socio-Cultural Sciences and state ideology (Pancasila) and methodology (philosophy). In the stem, knowledge appears, which refers to the foundation for the formation of scientific integration (al-Qur'an, al-Hadith, Sirah Nabawi, Islamic Thought and Islamic Societies). The knowledge cluster at the root and stem must be studied by each student in all study programs. After the students learn two knowledge in both the root and stem, they study especially and socially demanding knowledge, one that is required in sociocultural settings (the exact sciences, social sciences, and humanities), which is held by the faculty and study programs. In this third group, not all students learn a variety of knowledge, but quite a few students who study according to their specialization. In principle, all students study the fields of knowledge that exist on branch and leaf, but they choose them according to their interest in the study program.

This way enables the integration of general and religious knowledge in every academic community, and the graduates are expected to have spiritual depth, moral majesty, breadth of knowledge and professional maturity. It does not end here. UIN Maliki Malang also forms a campus-based religious culture environment, which is intended to equip graduates with these four characters, or commonly referred to as $u l \bar{u}$ al-Albāb. The integration of science and Islam in UIN Maliki Malang in practice tends to follow the Islamization model of knowledge with the Islamic justification of modern scientific method, but metaphorical integration is presented in the sufficient tree of science because the target is the academic community.

The second case is UIN Sunan Kalijaga, Yogyakarta. It promotes the paradigm of integration-interconnection with the "Spider Web" metaphor. The scientific view of integration- 
interconnection at this Islamic university is initiated by M. Amin Abdullah, one of the leading scholars that advance integrative thoughts between Islam and scientific, social and humanities disciplines. The integrative operation and methodological building of science and Islam derive from the scientific creativity of $\mathrm{M}$. Amin Abdullah. For this reason, it is not an exaggeration to state that Abdullah is the leading proponent of the integration of Islam and science in this university.

The paradigm of Islam-science integration in this university is based on several essential viewpoints. First, religion in the broad sense is God's revelation, which regulates the relationship between humans and God, oneself, and the environment physically, socially, culturally, and globally. This set of rules, universal values and basic principles, are called "shari'a" and are derived from the Quranic verses, such as Sura al-Jäthiya [18] and Sura al-Mā'ida [48]. The Qur'an encompasses ethics, morals and wisdom, and it can be the basis of the theology of science as well as the grand theory of science. It should be stressed that revelation should never be claimed to be science.

Second, a science born from religion becomes objective science (experiencing an objectification process). In a sense, that knowledge is not felt by adherents of other religions, nonreligions, and anti-religions as norms (side of normativity), but merely as an objective scientific phenomenon (the side of historicity). Believing a religious background, whether it is a source of knowledge or not, is not a problem. Science with a religious background is an objective science, not a normative religion.

Third, human knowledge can be classified into three, namely natural sciences, social sciences and humanities. It is an accident of the history of Muslims when the building of natural sciences (al-'ulum al-kawniyya) is separated and does not come into contact with Islamic sciences whose foundations are "text" (nașs). These separation and consolidation have a tremendous impact on the world of bureaucracy, the world of government, the world of SOE, business world, environment and the world of work in general. Therefore, we need a model of knowledge that is interconnected entities, in the sense that each is aware of its limitations in solving 
human problems. This then needs cooperation at least in terms of approaches and methods of thinking and research (process and procedure).

Therefore, in Islamic university institutions, the curriculum with the spirit of scientific ethos emphasizes the framework of interdisciplinary, sensitivity, and interconnection, with the breath of epistemological reintegration. Abdullah has stated that it was necessary to consider the basic principles, such as the civilization of the text (hadara al-nașs). The support of bayānit-text culture is no longer able to stand alone, regardless of the civilization of science (hadara al-ilm), such as engineering, communication; and also cannot be separated from civilization philosophy (hadara al-falsafa) and vice versa. Hadara al-ilmi (the culture of science), i.e. the empirical sciences that produce science and technology, will have no "character" in human life and the environment if it is not guided by the sturdy hadara al-falsafa (ethical-emancipatory culture). Meanwhile, the hadara al-nașs (a religious culture that solely refers to text) in combination with hadara al-'ilm (science and technology), without recognizing contemporary humanity, is also dangerous because if it is not carefully applied, it will easily be carried away towards the movement of radicalismfundamentalism. ${ }^{43}$ For this reason, it is necessary to have the hadara al-falsafa (a transformative-liberative culture of ethics). Likewise, the hadara al-falsafa (philosophical civilization) will be meaningless unless it is related to religious issues contained in the text culture, not to mention being away from the problems posed and faced by hadara al-ilmi (civilization of empirical-technical science). Considering interconnectedness of those elements, namely text, science, philosophy, history and civilization, it is

${ }^{43}$ M. Amin Abdullah, “Agama, Ilmu dan Budaya: Kontribusi Paradigma Integrasi-Inetrkoneksi Ilmu dalam Menghadapi Isu-Isu Islamic Studies Kontemporer," in Praksis Paradigma Integrasi-Interkoneksi dan Transformasi Islamic Studies di UIN Sunan Kalijaga, ed. M. Amin Abdullah et. al. (Yogyakarta: Pascasarjana UIN Sunan Kalijaga, 2014); Siswanto, "Perspektif Amin Abdullah Tentang Integrasi Interkoneksi dalam Kajian Islam," Teosofi: Jurnal Tasawuf dan Pemikiran Islam 3, no. 2 (2013): 376-409, http://teosofi.uinsby.ac.id/index. php/teosofi/article/view/35. 
necessary UIN should compose curriculum and coursework that integrate them with traditional Islamic religious science.

In the curriculum development of study program, Abdullah proposes to use interconnected schemes, i.e. combining the three basic principles -described in the previous paragraph-, and overriding the single scheme and isolated scheme which put the three civilizations separately. ${ }^{44}$ Integration-interconnection praxis or interconnected schemes in the development of knowledge to aims to perceive and resolve problems from various perspective. This integrative perspective can be applied, for example, to address the controversial legal issue of a child born from an unregistered married couple, as this happened to an Indonesian singer. ${ }^{45}$ Briefly, these problems are presented beneath:

“On February 17, 2012, the Constitutional Court (MK) decided on a new provision, perfecting article 43 paragraph 1 of the 1974 Marriage Law, stipulating that "children born outside of marriage have a civil relationship with their mothers and their families of mothers and with men as his fathers that can be proven based on science and technology and/or other evidence according to the law has a blood relationship, including civil relations with his father's family".

The court decision suggests that Islamic law cannot stay alone to address such a problem. One aspect that the law may deal with is concerned with the status of a child born out of unregistered marriage. According to the traditional interpretation of Islamic law, the child acquires a genealogical link to his/her parent (father and mother) so long as the parent has tied the knot in accordance to the standard of Islamic law. However, according to the state, the child has no genealogy to the father because the marriage is not recorded. This view may hamper the child's reputation, and future and this view are problematic. There must be a scientific examination as to who is the birth father of the child to solve this problem. Here medical and DNA examination help discovers the biological father of the child so that the child can be ascribed to him medically and thus legally. This approach is interdisciplinary

${ }^{44}$ Amin Abdullah, Islamic Studies, 95.

${ }^{45}$ M. Amin Abdullah, "Religion, Science and Culture: An Integrated, Interconnected Paradigm of Science," Al-Jami'ah: Journal of Islamic Studies 52, no. 1 (2014): 175-203, https://www.aljamiah.or.id/index.php/AJIS/article/view/52108. 
because it is involved not only Islamic law but also medical science.

Meanwhile, the issue that has become a controversy among Muslims almost every year is the determination of the end of Ramadhan fasting month and the beginning of ' $\overline{\mathrm{I}} \mathrm{d}$ al-Fitr. This dispute is triggered by the use of single religious knowledge or science without integrating with other related science. The struggle (not to call it the Conflict paradigm) between religion and science is always displayed in the public space, and there are no signs of ending in the near future. Conflict or difference between the system of calculation of the beginning of the Ramadhan month through ru'ya (see the beginning of the month empirically using the naked eye-which is assisted by a telescope) and the system of calculating the beginning of the month through hisāb (mathematical rational calculations) as practiced in calculating the miladiyya calendar (Gregorian) all this time best illustrate this uninterrelated perspective. If the medieval conflict was triggered by differences in understanding and interpretation of the church and the calculation of astronomic scientists about planetary motion, that is, between geocentric and heliocentric schools, then the conflict in the modern era, at least in Indonesia and in the Muslim world in general, is the determination of the beginning of the Ramadhan month between ru'ya experts and hisāb experts. This disagreement of determining method poses socio-religious problems in the Muslim community for they may celebrate the end of Ramadhan less prepared. Muslims may also hold $\bar{I} d$ al-Fitr separately in different date, place and time.

These two examples should be valuable lessons for Muslims about the importance of using an integration-interconnection approach in solving social, humanitarian or even religious issues at once. The confinement in one approach in solving problems not only shows weakness, but it will also create new complicated problems. On this ground, the proponent of Islam-science integration at UIN Sunan Kalijaga build their argument, that knowledge is both religiously and scientifically grounded.

Third, the integration-multidisciplinary paradigm of UIN Sunan Ampel Surabaya with a metaphor of "Integrated Twin Tower". The background of scientific development with the 
integrative-multidisciplinary paradigm arose from the intellectual unrest of the UIN academic community itself. This anxiety arose from Islamic studies which developed more thickly with a rational-speculative approach with deductive character; meanwhile, a practical empirical approach with an inductive character lacked a decent place. This condition has caused Islamic scientific development in Islamic universities to be relatively stagnant because of the robust normative-theological approach. Consequently, it tends to justify religious teachings, doctrines and norms. Islamic studies are ultimately less grounded because they do not rest on empirical reality; even the nuances of normative study of this field are very thick. Likewise, Islamic sciences also experience a crisis of relevance to the dynamics of society, and the concrete problems of the community is growing. This is the epistemological problem of scientific development in general in Islamic universities, especially at UIN Sunan Ampel Surabaya. ${ }^{46}$

The view of the approach to Islamic studies finally encourages UIN Sunan Ampel Surabaya to integrate Islamic sciences with other sciences in order to be more dynamic and developed, such as the need for religious studies to be enriched with social sciences, or natural sciences with Western philosophy, sociology and anthropology, or with empirical science. Thus there will be a synthesis between the normative-metaphysical dimensions and the historical-empirical dimension so that there is a dynamic dialectical-constructive process in answering academic and social problems. The phrase "we talk about God in the sky, while we are still lying on the earth" is overtaken by the pretext of the unity of science and religion. In the future, natural science is axiologically

${ }^{46}$ Umi Hanifah, "Islamisasi Ilmu Pengetahuan Kontemporer: Konsep Integrasi Keilmuan di Universitas-Universitas Islam Indonesia," Tadris: Jurnal Pendidikan Islam 13, no. 2 (2018): 273-294, http://ejournal.iainmadura.ac.id/index. php/tadris/article/view/1972; Ahmad Sukron, "Paradigma Islamisasi Ilmu Pengetahuan di PTAIN: Studi Komperatif tentang Konsep Pengembangan Keilmuan dengan Model Pohon Ilmu di UIN Malik Ibrahim Malang dan Twin Towers di UIN Sunan Ampel Surabaya" (Thesis, UIN Sunan Ampel, 2011); A. Muzakki, "Model Pembelajaran Integrated Twin Towers," accessed July 2, 2018, http://arsipuinsa.uinsby.ac.id/index.php/19-uinsa/kolom-akademisi/98-modelpembelajaran-integrated-twin-towers-serial-1. 
and continuously developed for the purpose of advancing human civilization.

The integrative-multidisciplinary model in scientific development at UIN Sunan Ampel Surabaya is laid on the fundamental view that Islamic, social-humanities and natural sciences must develop adequately and fairly. This science can be grouped into two parts: Islamic sciences and modern sciences. Both are considered to have the same authority so that one another does not feel superior or inferior to each other. Islamic science has developed in its capacity, and development possibilities, as well as other modern sciences, have also developed in its range and capacity. Islamic sciences are like one tower, and another science is like the other tower. Both of them are connected and integrated through multidisciplinary Islamic science concept. One tower becomes the subject matter and the other as an approach; this is what is meant by the integration-multidisciplinary model at this Islamic university. ${ }^{47}$

The integration-multidisciplinary paradigm that UIN Sunan Ampel adopted has several characteristics. First, the integration is symbolized by its twin building. Second, Islamic science is integrated with social-humanitarian sciences and science and technology according to the specific characters and objects they have, but they remain interconnected to each other. Third, the integration is not similar to the Islamization of knowledge. Instead, it promotes Islamization of reason needed for the creation of complementary scientific systems between Islamic sciences, social-humanitarian sciences, as well as science and technology. This means that the integrative-multidisciplinary paradigm does not intend to merge Islamic sciences into modern science or even vice versa. That is, this is not like the model of Islamization of science, which tends to be reactive and intervenes in established modern science. ${ }^{48}$

${ }^{47}$ Tim UIN Surabaya, Desain Akademik UIN Sunan Ampel Surabaya (Surabaya: UIN Sunan Ampel Press, 2013). See also in Husniyatus Salamah Zainiyati, Kurikulum IAIN Menuju UIN Sunan Ampel: Dari Pola Pendekatan Dikotomis ke Arah Integratif Multidisipliner-Model Twin Towers (Surabaya: UIN Sunan Ampel Press, 2016), 47.

${ }^{48}$ Syaifuddin Syaifuddin, "Integrated Twin Towers dan Islamisasi Ilmu," 
There are fascinating facts, epistemologically an integrativemultidisciplinary scientific paradigm with the metaphor of integrated twin towers described in "Desain Akademik UIN Sunan Ampel Surabaya" (Academic Design of UIN Sunan Ampel Surabaya). In the description, it is explained as follow. ${ }^{49}$ First, integrated twin towers at UIN Sunan Ampel Campus are metaphor reflecting two different discipline; one tower for Islamic science while the other for social-humanitarian sciences, science and technology. The twin tower is connected with connecting bridges and three pillars as their support, namely strengthening pure Islamic sciences by integration between "Islamic scientific development" and social-humanitarian sciences, and scientific and technological weighting with Islamic science. Second, empowering pure Islamic sciences includes aqìda (theology and creed) science, the Qur'anic Sciences, the Hadith Science, figh (sharia law) science and falak (astronomy) science. Strengthening of pure Islamic sciences is conducted by market research and curriculum review to ensure the needs that arise and must be fulfilled. There are practical needs of pure sciences in society, while the competencies of existing graduates are inadequate. Strengthening these pure sciences becomes relevant and essential to answer market needs. Third, there is a need for the integration between "Islamic scientific development" and social-humanitarian science. Islamic sciences with the social-humanitarian sciences have so far been positioned mutually excluded or at least unrelated. In this view, these two sciences are ontologically and epistemologically different and cannot be reconciled. In a situation like this, UIN Sunan Ampel Surabaya takes the position of integrating Islamic science of development, such as Islamic history and politics with the socialhumanitarian sciences which are still considered secular. The integrative-multidisciplinary paradigm seeks to bring together, converse and complement each other. The integration of the two sciences is carried out in two ways at once, i.e. through a study

Jurnal Pendidikan Agama Islam (Journal of Islamic Education Studies) 1, no. 1 (2013): 1-20, accessed December 4, 2019, http://jurnalpai.uinsby.ac.id/index.php/ jurnalpai/article/view/1.

${ }^{49}$ Tim UIN Surabaya, Desain Akademik UIN, 34-36. 
perspective and targets. If the Islamic sciences of development are positioned as the target of study, the social-humanitarian sciences are positioned as an approach and vice versa.

Fourth is the exact weighting of science and technology with Islamic sciences. Weighting is conducted by Islamizing the lecturers' and students' reasoning, especially those who pursue the field of social-humanities as well as the field of science and technology. The technique of weighting is carried out through the Islamic Studies Mainstreaming Program in the form of compulsory workshops to increase Islamic scholarship. This program has two interests at once, i.e., ensuring adequate Islamic knowledge and understanding of lecturers, especially for socialhumanitarian sciences as well as science and technology lecturers, and the ability to synergize between social-humanities and science and technology with Islamic science.

The integrative-multidisciplinary scientific paradigm is expected to be able to create graduates with the characteristics of $u l \bar{u}$ al-Albāb (knowledgeable), i.e. the integration of the practice of dhikr (spiritual/chanting) and fikr (reason) in life (referring to Sura al-Zumar: 9 and Sura Āli 'Imrān: 7) and maturity and taking the best choices in life based on divine instructions (Sura al-Zumar 18 and Sura al-Mā'ida: 100), and intellectual establishment (Sura Alī 'Imrān: 18 and 190). This paradigm also facilitates the creation of intellectual property, spiritual maturity, and behavioural wisdom. Furthermore, the intellectual property produces smart personality, the wisdom of behaviour produces pious personality, and spiritual maturity creates honourable (dignified) personality.

\section{Conclusion}

Integration of science and Islam is a necessity now onwards. Integrated knowledge is critical to solving various increasingly complex community problems. Increasingly complex environmental problems, legal issues, economic problems, and political issues are no longer sufficient to be solved with the dichotomic knowledge, as this was generally adopted by Islamic higher educational institution in the past several decades ago, and implicitly in some current institutions, which has not transformed 
into university and still applied single approach of pure Islamic studies.

The Integration of knowledge is not enough only by associating science and Qur'anic verses or Hadith, or by justification, as this has been adopted in the initial process of Islam and science integration. The integration in Islamic universities must begin by compiling a philosophical foundation and taking necessary methodological steps. Experiments carried out by several Islamic universities that this study shows can use as a model for the rest Islamic universities that envision the same project. However, further analysis of the practical level of Islamscience integration, its implementation and impact on Islamic thoughts need to be conducted for further study since this is beyond the reach of this current study.

\section{References}

Adawiyah, Rabiatul. "Integrasi Sains dan Agama dalam Pembelajaran Kurikulum PAI (Perspektif Islam dan Barat serta Implementasinya)." Al-Banjari: Jurnal Ilmiah Ilmu-Ilmu Keislaman 15, no. 1 (May 15, 2016): 99-124. http://jurnal.uinantasari.ac.id/index.php/al-banjari/article/view/817.

Al-Attas, Syed Muhammad Naquib. Islam and Secularism. Kuala Lumpur: ISTAC, 1993.

Amin Abdullah, M. "Agama, Ilmu dan Budaya: Kontribusi Paradigma Integrasi-Inetrkoneksi Ilmu dalam Menghadapi Isu-Isu Islamic Studies Kontemporer." In Praksis Paradigma Integrasi-Interkoneksi dan Transformasi Islamic Studies di UIN Sunan Kalijaga, edited by M. Amin Abdullah et. al. Yogyakarta: Pascasarjana UIN Sunan Kalijaga, 2014.

- - - . Islamic Studies di Perguruan Tinggi Pendekatan IntegratifInterkonektif. Yogyakarta: Pustaka Pelajar, 2006.

- - . "Religion, Science and Culture: An Integrated, Interconnected Paradigm of Science." Al-Jami'ah: Journal of Islamic Studies 52, no. 1 (2014): 175-203. https://www.aljamiah. or.id/index.php/AJIS/article/view/52108.

Anshori, and Zaenal Abidin. "Format Baru Hubungan Sains

Modern dan Islam (Studi Integrasi Keilmuan Atas UIN 
Yogyakarta dan Tiga Universitas Islam Swasta Sebagai Upaya Membangun Sains Islam Seutuhnya Tahun 2007-2013)." Profetika Jurnal Studi Islam 15, no. 1 (June 6, 2016): 90-108. http://journals.ums.ac.id/index.php/profetika/article/view/196 9.

Aziz, Abdul. "Paradigma Integrasi Sains dan Agama: Upaya Transformasi IAIN Lampung Kearah UIN." Al-Adyan: Jurnal Studi Lintas Agama 8, no. 2 (2013): 67-90. http://ejournal. radenintan.ac.id/index.php/alAdyan/article/view/587.

Badarussyamsi. "Spiritualitas Sains Dalam Islam: Mengungkap Teologi Sainstifik Islam." MIQOT: Jurnal Ilmu-ilmu Keislaman 39, no. 2 (2015): 255-275. http://jurnalmiqotojs.uinsu.ac.id/ index.php/jurnalmiqot/article/view/17.

Bakar, Osman. Hierarki Ilmu, Membangun Rangka Pikir Islamisasi Ilmu: Menurut al-Farabi, al-Ghazali, Qutb al-Din al-Syirabi. Translated by Purwanto. Bandung: Mizan, 1998.

Barbour, Ian G. "On Typologies for Relating Science and Religion." Journal of Religion \& Science 37, no. 2 (2002): 345-360. https://onlinelibrary.wiley.com/doi/abs/10.1111/0591-2385.00432. - - - When Science Meets Religion. New York: Harper SanFrancisco, 2002.

Bucaille, Maurice. The Bible, The Qur'an, and Science: The Holy Scriptures Examined in The Light of Modern Knowledge. New York: American Trust Publications, 1978.

Draper, John William. History of The Conflict Between Religion and Science. New York: D. Appleton and Company, 1986.

al-Faruqi, Ismail Raji'. Islamization of Knowledge: General Principles and Work Plan. Herndon: IIIT, 1989.

Guessoum, Nidhal. Islam Dan Sains Modern: Bagaimana Mempertemukan Islam Dengan Sains Modern. Translated by Maufur. Bandung: Mizan, 2014.

Hanifah, Umi. "Islamisasi Ilmu Pengetahuan Kontemporer: Konsep Integrasi Keilmuan di Universitas-Universitas Islam Indonesia." Tadris: Jurnal Pendidikan Islam 13, no. 2 (2018): 273294. http://ejournal.iainmadura.ac.id/index.php/tadris/article/ view/1972.

Hayat, Hayat. "Integrasi Agama dan Sains Melalui Mata Kuliah PAI di Perguruan Tinggi." INSANIA: Jurnal Pemikiran 
Alternatif Kependidikan 19, no. 2 (2014): 254-272. http://ejournal. iainpurwokerto.ac.id/index.php/insania/article/view/715.

Heriyanto, Husein. Paradigma Holistik: Dialog Filsafat, Sains, dan Kehidupan Menurut Shadra dan Whitehead. Jakarta: Teraju, 2003. Hoodbhoy, Pervez. Ikhtiar Menegakkan Rasionalitas antara Sains dan Ortodoksi Islam. Translated by Sari Meutia. Bandung: Mizan, 1996.

Idris, Jaafar Sheikh. "The Islamization of the Sciences: Philosophy and Methodology." The American Journal of Islamic Social Sciences 4, no. 2 (1987): 201-208.

Iqbal, Muzaffar. Science and Islam. London: Greenwood Press, 2007. Kartanegara, Mulyadhi. Integrasi Ilmu: Sebuah Rekonstruksi Holistik. Bandung: Arasy, 2005.

- - - Nalar Religius: Memahami Hakikat Tuhan, Alam, dan Manusia. Jakarta: Erlangga, 2007.

Khozin. Pengembangan Ilmu di Perguruan Tinggi Keagamaan:

Konstruksi Kerangka Filosofis dan Langkah-langkahnya. Jakarta: Kencana, 2016.

Lukens-Bull, Ronald A. Islamic Higher Education In Indonesia: Continuity and Conflict. New York: Palgrave McMillan, 2013.

- - - . "The Political Use of Islamic Variation in Indonesia Islamic Higher Education." Jurnal Pendidikan Islam 2, no. 2 (2016): 193207. https://journal.uinsgd.ac.id/index.php/jpi/article/view/786.

Lukman, Fadhli. "Integrasi-Interkoneksi Dalam Studi Hadis

Disertasi UIN Sunan Kalijaga Yogyakarta." Religia: Jurnal IlmuIlmu Keislaman 12, no. 2 (February 20, 2017): 1-11. Accessed June 3, 2019. http://e-journal.iainpekalongan.ac.id/index.php/ Religia/article/view/746.

Maksudin. Paradigma Agama dan Sains Nondikotomik. Yogyakarta: Pustaka Pelajar, 2016.

Mufid, Fathul. “Islamic Sciences Integration.” Qudus International Journal of Islamic Science 2, no. 2 (2014): 144-160. http://journal. stainkudus.ac.id/index.php/QIJIS/article/view/1565.

Muflihin, Ahmad. "Paradigma Keilmuan Integrasi-Interkoneksi: Studi Terhadap Desain dan Implementasi Kurikulum Program Magister Prodi Pendidikan Islam Fakultas Ilmu Tarbiyah dan Keguruan UIN Sunan Kalijaga Yogyakarta." Thesis PostGraduate, UIN Sunan Kalijaga, 2016. 
Munadi, Muhammad. "Integration of Islam and Science: Study of Two Science Pesantrens (Trensain) in Jombang and Sragen." Jurnal Pendidikan Islam 5, no. 2 (December 15, 2016): 287-303. http://ejournal.uin-suka.ac.id/tarbiyah/index.php/JPI/article/ view/1236.

Mustikan Sari, Ramadhanita. "Perguruan Tinggi Islam dan Transformasi Lembaga: Studi Terhadap Proses Perubahan Fungsi dan Peran IAIN Syarif Hidayatullah Jakarta Menjadi Universitas Islam." El-Hekam 1, no. 1 (2016): 1-18. http://ecampus.iainbatusangkar.ac.id/ojs/index.php/elhekam/a rticle/view/334.

Muzakki, A. "Model Pembelajaran Integrated Twin Towers." Accessed July 2, 2018. http://arsipuinsa.uinsby.ac.id/index. php/19-uinsa/kolom-akademisi/98-model-pembelajaranintegrated-twin-towers-serial-1.

Nasr, Seyyed Hossein. Menjelajah Dunia Modern. Translated by Histi Tarekat. Bandung: Mizan, 1994.

Nur Arifa, Laily. "Perubahan STAIN/IAIN Menjadi UIN Sebagai Bentuk Pengembangan Pendidikan Tinggi Islam: Contoh Kasus Perubahan STAIN Menjadi UIN Malang Perspektif Manajemen Perubahan Kurt Lewin." Vicratina: Jurnal Pendidikan Islam 2, no. 1 (2017): 27-42. http://riset.unisma. ac.id/index.php/fai/article/view/265.

Rahman, Fazlur. "Islamization of Knowledge: A Response." Islamic Studies 50, no. 3/4 (2011): 449-457. www.jstor.org/ stable/41932607.

Sardar, Ziauddin. Rekayasa Masa Depan Peradaban Muslim. Translated by Rahmani Astuti. Bandung: Mizan, 1993.

- - - ed. The Touch of Midas: Science, Values and Environment in Islam and the West. Manchester: Manchester University Press, 1984.

Sholeh. "Islamisasi Ilmu Pengetahuan: Konsep Pemikiran Ismail Raji al-Faruqi dan Syed Muhammad Naquib al-Attas." alHikmah: Jurnal Agama dan Ilmu Pengetahuan 14, no. 2 (2017): 209-221.

https://journal.uir.ac.id/index.php/alhikmah/article/view/1029. Siswanto. "Perspektif Amin Abdullah Tentang Integrasi Interkoneksi dalam Kajian Islam." Teosofi: Jurnal Tasawuf dan 
Pemikiran Islam 3, no. 2 (2013): 376-409. http://teosofi.uinsby. ac.id/index.php/teosofi/article/view/35.

Soewardi, Herman. Roda Berputar Dunia Bergulir: Kognisi Baru

Tentang Timbul Tenggelamnya Sivilisasi. Bandung: Bakti Mandiri, 1999.

Sukron, Ahmad. "Paradigma Islamisasi Ilmu Pengetahuan di

PTAIN: Studi Komperatif tentang Konsep Pengembangan

Keilmuan dengan Model Pohon Ilmu di UIN Malik Ibrahim

Malang dan Twin Towers di UIN Sunan Ampel Surabaya."

Thesis, UIN Sunan Ampel, 2011.

Suprayogo, Imam. "Pendidikan Integralistik: Memadu Sains dan

Agama." In Memadu Sains dan Agama Menuju Universitas Islam

Masa Depan, edited by M. Zaenuddin et.al. Malang: UIN Malang Press, 2004.

Suyatman, Ujang. "Manajemen Strategik dalam Transformasi IAIN Menjadi UIN." Jurnal Administrasi Pendidikan 14, no. 1 (2012): 33-59. https://ejournal.upi.edu/index.php/JAPSPs/ article/view/6705.

Syaifuddin, Syaifuddin. "Integrated Twin Towers dan Islamisasi Ilmu." Jurnal Pendidikan Agama Islam (Journal of Islamic Education Studies) 1, no. 1 (2013): 1-20. Accessed December 4, 2019. http://jurnalpai.uinsby.ac.id/index.php/jurnalpai/article/ view/1.

Tafsir, Ahmad. "Basis Filsafat untuk Integrasi Pengetahuan Quraniyah dan Pengetahuan Kauniyah." In The International Seminar UIN Sunan Gunung Djati Bandung, 2011.

Taufik, Muhammad, and Muhammad Nasir. “Mengkritisi Konsep Islamisasi Ilmu Ismail Raji al-Faruqi: Tela'ah Pemikiran Ziauddin Sardar." Jurnal Ushuluddin 25, no. 2 (2017): 109-123. http://ejournal.uin-suska.ac.id/index.php/ushuludin/article/ view/3830.

Tim UIN Surabaya. Desain Akademik UIN Sunan Ampel Surabaya. Surabaya: UIN Sunan Ampel Press, 2013.

Tipler, Frank J. The Physics of Christianity. Toronto: Doubleday, 2007.

Wahab, Muhbib Abdul. "Pendidikan Islam Holistik Berbasis Nilai dalam Perspektif Sirah Nabi." In Pendidikan Holistik: 
Pendekatan Lintas Pespektif, edited by Jejen Musfah. Jakarta: Kencana, 2012.

Wan Daud, Wan Mohd Nor. Filsafat dan Praktik Pendidikan Islam Syed M. Naquib al-Attas. Translated by Hamid Fahmy et.al. Bandung: Mizan Media Utama, 2003.

Wiwaha, Kurnia Sari. "Epistemologi Paradigma Islam: Studi Pemikiran Ziauddin Sardar." Religious: Jurnal Studi AgamaAgama dan Lintas Budaya 3, no. 1 (2018): 70-79. http://journal. uinsgd.ac.id/index.php/Religious/article/view/3673.

Zainiyati, Husniyatus Salamah. Kurikulum IAIN Menuju UIN Sunan Ampel: Dari Pola Pendekatan Dikotomis ke Arah Integratif Multidisipliner-Model Twin Towers. Surabaya: UIN Sunan Ampel Press, 2016.

Zainuddin, M. "Integration of Science and Islam: A Concept and Experience of Maulana Malik Ibrahim State University Malang-Indonesia." Paper presented at the Workshop Reformulasi Integrasi Sains dan Islam di Perguruan Tinggi, PSIS UIN Malang, September 16, 2014.

Zuhdiyah. "Islamisasi Ilmu Ismail Raji al-Faruqi." Tadrib: Jurnal Pendidikan Agama Islam 2, no. 2 (2016): 293-313. http://jurnal.radenfatah.ac.id/index.php/Tadrib/article/view/11 73. 